\title{
The Impact of Immigration Legislation on Latino Families: Implications for Social Work
}

\author{
Sylvia Romero \\ Melissa Romero Williams
}

\begin{abstract}
Under the Obama administration, approximately 1.2 million undocumented immigrants have been deported, (around 400,000 in 2011), placing children (who are often American citizens) at risk of unnecessary mental anguish as well as financial hardship. With republican and democratic leadership tied up in ideological debates addressing the issue of comprehensive immigration reform, many states are left in a dire position and we as a nation end up with draconian anti-immigrant legislation that places more Latino immigrant families at risk. Enforcement-only initiatives leave children and families of immigrants in our country vulnerable. Comprehensive immigration reform is necessary. This article discusses the prevalence of such policy initiatives and their implications for social work education, practice, research, and policy.
\end{abstract}

Keywords: Immigration legislation, Latino children and families, immigrants

Throughout the history of the United States, there have been at various points in time, different immigrant, ethnic, and racial groups who have suffered the negative impact of political, legal, economic, and social ramifications resulting from increases and changes in the demographic patterns of the immigrant population (Atkinson as cited in Casas \& Cabrera, 2011). Following the September 11, 2001 attacks, John Ashcroft (United States Attorney General) declared that immigration rules would be the primary weapon against terrorism, and targeted Arab, Muslim, and South Asian men who were living in the United States (Critelli, 2008). "The economic and psychological effects of September 11 have been compounded by the additional toll the response to the attacks has taken on civil liberties and human rights" (Critelli, 2008, p. 146). Hate crimes and anti-immigrant legislation have festered nationally. Although, undocumented immigrants come from many countries and include diverse racial and ethnic populations, Latinos have primarily been targeted nationally in the enforcement of anti-immigrant legislation (Casas \& Cabrera, 2011). This has had an adverse effect on Latino families. Comprehensive immigration reform is needed. This article will address the impact of immigration legislation on Latino families and the role that social work practice, education, policy, and research have in affecting social justice and reform.

From 1990 to 2007, the largest growth of children (between the ages of 0 to 17) born in the United States were children of immigrants, and nationally 56\% were Latinos (Fortuny, 2010). Fortuny (2010) reported that beyond that, the breakdown of children of immigrants continues where 22\% were from Asia; 11\% from Canada, Europe, and Australia; 10\% were from the Pacific and East Asia; 8\% were from South Asia and the Middle East; 8\% from the West Indies and Africa, and 4\% were from Southeast Asia. Fix and Passel (2003) reported that 1 in 5 school-aged children (k-12) are children of

Sylvia Romero, Ph.D., MSW, C-SSWS, is a School Social Worker at Community Consolidated School District \#46, Grayslake, IL. Melissa Romero Williams, MA, LPC, is a Counselor at Deerfield High School, Deerfield, IL. 
immigrants (10.5 million); three quarters of whom are born in the United States, while one quarter were foreign-born. Dolan (2009) concurred that one fifth of school-aged children were Latinos, 91\% of which were U.S. citizens.

Knight (2012) reported that according to the Office of Refugee Resettlement 8,244 unaccompanied children (undocumented) entered the United States last year. According to Capps, Castañeda, Chaudry, and Santos (2007) "in 2005 there were 9.3 million unauthorized working-age adults (18-64) and 4.9 million children (ages 0-17) living with these unauthorized adults” (p. 91). Wessler (2011) reported that there were 11 million undocumented immigrants; 5.5 million children of undocumented immigrants of which 4.5 million were U.S. citizens. Bess (2011) concurred that approximately 5.5 million children lived with at least one undocumented parent. For every two deportations, one child was left behind, placing the children emotionally, economically, and socially at risk (Capps et al., 2007).

Since the April 2010 passage of SB 1070, Arizona has been at the forefront of the anti-immigrant movement. With the growing number of anti-immigrant laws, the writers of legislation are placing the mental and emotional health and well-being of Latino children (whose parents are undocumented) and their families at risk. The Jim Crow type legislation legalizes racial profiling, discrimination, and the unnecessary harassment of Latinos (immigrants and United States citizens), as well as the exploits of undocumented workers. According to Cleary (2000) "racial profiling occurs when a law enforcement officer uses race or ethnicity as one of several factors to stop, question, arrest, and/or search someone” (p. 6). Six states, Arizona, Utah, Indiana, Alabama, Georgia, and South Carolina, have enacted such laws. Six states are considering copycat bills or have locally enacted anti-immigrant enforcement policies in various counties (Illinois, Wisconsin, Mississippi, Michigan, Ohio, and Pennsylvania) and 18 states attempted but failed to pass copycat bills in 2011 (Southern Poverty Law Center [SPLC], 2011b). The National Council of La Raza (NCLR: 2011a; 2011b) has been following the national copycat landscape. Alabama's HB 56 is one of the harshest immigration laws and it has been in effect since June 2012. Alabama's HB 56 has terrorized (Latino) families and children who are now afraid to go to school, since schools are required to check on the immigration status of the students (SPLC, 2011a). Parents are denied the right to attend their children's school functions without a State of Alabama ID. Among other things, if a person does not have a State of Alabama ID card, that person is denied a water service connection, regardless of their ability to pay the fee. In addition, immigration documents must always be carried by all immigrants. According to the Southern Poverty Law Center, a victim of domestic violence was threatened with deportation if she pursued seeking a court order of protection by a judge elected to serve the community. It is important to note that victims of abuse qualify for U-visas, and victims of trafficking qualify for T-visas according to the Department of Homeland Security (DHS). Immigration and human and civil rights advocates consider HB 56 the most draconian anti-immigrant law (Lewis, 2011). 


\section{Secure Communities}

Congress intended for the United States Immigration and Customs Enforcement (ICE) "Secure Communities" program to be used as a tool to assist local police to "identify aliens convicted of a crime, sentenced to imprisonment, and who may be deportable” (Illinois Coalition for Immigrant and Refugee Rights [ICIRR], 2011, p. 4). The overall goal of this program was to deport criminals who were undocumented. Yet, the program has swept up immigrants (fathers, mothers, and students) with no criminal convictions, and who have not posed harm to the community, resulting in separated families. Congress has referred to this as "Collateral Damage." "More than three-quarters (77\%) of all immigrants arrested by ICE in Illinois under 'Secure Communities' through July 2010 have no criminal convictions” (ICIRR, 2011, p. 1). As of November 2011, 969 counties in 37 states signed onto 'Secure Communities' (Illinois signed on November 2009) and further participation is expected nationwide by 2013. Local law enforcements agencies in many states and cities can enforce immigration laws for any minor state law infraction. This has had a negative impact on the families, and in particular the children who have increased stress levels due to the fear of deportation and separation from their undocumented parents.

According to the ICIRR (2011), “Secure Communities” encourages racial profiling. For example, many local police set up checkpoints and other operations to target Latinos and other immigrants for minor traffic infractions like windshield obstructions. Federal law requires that detainees be held for only 48 hours, yet often they are held in jails for two weeks until ICE arrives, which costs taxpayers money. "Secure Communities" also undermines the normal trust between immigrant communities and the police. There is a lack of transparency as ICE has not published any figures on the numbers of identified immigrants, arrests, and deportations (after litigation) since September 2010, and since July 2010 for county-level. Counties are not allowed to opt out.

"Secure Communities" was enacted to keep communities safe by primarily deporting undocumented "criminals," yet it has increased racial profiling and has targeted parents, and students for minor vehicle infractions. Once the local police departments have initiated participation with "Secure Communities" they are not allowed to opt out even though some Sheriffs have spoken out against this program. There is also a lack of transparency (since the year 2010) even when data has been requested under the Freedom of Information Act.

The following will address how "Secure Communities" along with workplace raids has impacted detentions and deportations, detention centers, and foster care placement.

\section{Detentions and Deportations}

Between 2002 and 2006 the number of workplace raids that led to the arrest of undocumented immigrants increased sevenfold from 500 to 3600 (Capps et al., 2007). Deportations hit a record high (nearly 400,000) in 2011 under the Obama administration (SPLC, 2011b). Jorge Ramos (Al Punto con Jorge Ramos, 9/2/2012) reported that approximately 1.2 million undocumented immigrants have been deported in the four years of the Obama administration. The detentions and deportations of mothers and 
fathers have emotionally and economically placed their children at risk by dividing the family (Critelli, 2008). Many children who are American citizens have returned (with their undocumented parents) to countries that are foreign to them.

\section{Detention Centers}

Bernstein (2011) reported that companies are making a massive profit with detention centers, jails, and prisons used for immigration detention globally, particularly in the United States, Britain, and Australia. Bernstein (2011) and FRONTLINE (2011) also noted that widespread abuse, neglect, and death have occurred in the detention settings, and human rights groups have advocated that detention has not worked as a deterrent, nor has it accelerated the deportation process. Currently, Corrections Corporation of America (CCA) targeted Crete, Illinois to build a new immigrant detention facility after the State Senate voted (53-1) to ban the building of private prisons in Illinois (ICIRR, 2012). According to the ICIRR (2012), in order to circumvent state law, ICE and the federal government are negotiating with the City of Crete rather than the State of Illinois.

\section{Foster Care Placement}

Chaudry and colleagues (2010) reported that ICE issued guidelines that "FOTs should not take into custody children under age 18 who are citizens or permanent residents but instead should refer them, in order, to child welfare authorities, local law enforcement agencies, or a third party designated by the parent” (p. 20). According to Wessler (2011), in some cases ICE contacts the Child Protection Services (CPS) following the arrest of an undocumented immigrant, and in other cases the parents are just detained.

Wessler (2011) identified at least 22 states where victims of domestic violence are arrested, detained, and separated from their children, and consequently have no idea where their children are. The undocumented victims of domestic violence will be at risk of further abuse and possible death, out of fear of deportation and separation from their children. These are human rights and social justice issues.

Wessler (2011) reported that 46,000 of those deported between January and June of 2011 were parents of children who are American citizens. Typically, when a child has been in foster care for 15 of any 22 months, "federal law requires CPS to petition the court to terminate parental rights (Wessler, 2011, p. 7). There are 5,100 children of deported or detained parents currently in foster care (Democracy Now Organization, 2011; Wessler, 2011). According to Wessler (2011), if nothing changes, and no action is taken, this number will increase to 15,000 in 5 years.

Most child welfare departments do not have systemic policies aimed at uniting the deported or detained families. Thus, the children are separated for extended periods and sometimes permanently. The implications for the emotional well-being of both the children and the parents are devastating, since the immigration detention severs communication between the families (Wessler, 2011). The American Humane 
Association (AHA: 2010) noted that children (including the children of immigrant families) who are placed in the child welfare system often lack a strong relationship with their caregiver, which is their most critical protective factor. Bowlby's attachment theory is highly relevant when addressing the impact that separating children from their undocumented parents has on the emotional well-being of the Latino children.

\section{Attachment Theory}

Children are one of our most vulnerable populations and they need our protection and guidance. Children are developmentally dependent on their parents and rely on their parents for all of their basic needs (care and nurturing, protection, emotional, and financial well-being) (Romero, 2006, 2009). According to Bowlby (1980), a child's loss or separation from a mother figure/caregiver can evoke psychopathology. There also appears to be a link between childhood separation and loss and adult psychopathology. Thus given Bowlby's research on attachment theory, the anti-immigrant legislation and laws are placing Latino children (and the children of other immigrants) at risk of increased psychological duress due to the separation from their parents caused by detentions, deportations (removals), and the children's placement into foster care. Psychologists are concerned that depression and other mental health issues can affect children who are separated from their undocumented parents (Capps et al., 2007). According to studies, immigrants may not experience more psychological distress or mental illness than nonimmigrants (Alegria, Canino, Stinson, \& Grant as cited in the American Psychological Association [APA], 2012). "When immigrants do experience mental health difficulties, for many it is related to the immigration experience" (APA, 2012, p. 8). Leaving their country of origin and their extended families behind to live in another country where language, customs, and life as they knew it, are new, is a huge culture shock for many. For the undocumented immigrants it is compounded given the current immigration legislations because the children and parents face the fear of separation from one another due to the undocumented status of the parents and/or children, and this can cause toxic stress. The toxic stress affects both the undocumented immigrants and their children, many of whom are American citizens by birth and are due the same protections and rights as any child born in this country based on the United States constitution. The children are integrated in the community, schools, and every facet of life in the United States, and this is the only place they know as home. "Exposure to violence and other sources of toxic stress is considered a serious public health issue around the world because of its impact on individuals, families, communities, and societies" (AHA, 2010, p. 9). A strong relationship with the caregiver is a critical factor that is necessary for children to fare well.

The following section will address education, the Dream Act, the use of prosecutorial discretion, the contributions of immigrants as job creators and tax contributors, and conclude with considering the implications for social work practice, education, policy, and research. 


\section{Education}

Education is one of the basic human rights. Dolan (2009) reported that $20.5 \%$ of all school-aged children are Latino, and 91\% are citizens of the United States. Latino children account for $24 \%$ of the population under the age of five, yet they are grossly underrepresented in early childhood programs (Dolan, 2009; Perez, 2000). Latino and Black children are more likely to attend schools with a higher concentration of poverty. Furthermore, Dolan reported that Latinos are most likely to attend community colleges; less likely than all racial groups to obtain financial assistance to obtain a bachelor's degree; and less likely to have expectations of receiving a bachelor's degree.

According to Faulkner and Berger Cardoso (2010) immigrant children had poorer outcomes in adulthood when compared to non-immigrant peers. Furthermore, children who immigrated to the United States prior to the age of 12 (generation 1.5), fared lower in economic advantage and job prestige when compared to $2^{\text {nd }}$ generation individuals (Faulkner \& Berger Cardoso, 2010). There is a positive correlation between higher GPAs and higher job prestige. Educational attainment is lower for immigrant children than nonimmigrant peers. Latino children have the lowest educational attainment rates in the country and the highest drop-out rates, exceeding both white and black students (Lopez, 2005; Olivos \& Mendoza, 2010). Chaudry and Fortuny (2010) reported that immigrant families had lower wages and income.

Despite the Supreme Court's Plyler v. Doe decision that held the entitlement of undocumented children to receive a primary and secondary state-funded education and educational equality, the undocumented children are caught in the midst of the “immigration crisis” (Lopez, 2005; Olivos \& Mendoza, 2010). Alabama’s anti-immigrant legislation is reported to deter the enrollment of children of immigrants by verifying the immigration status of the children and their parents (SPLC, 2011a). The State Superintendent of Education in Alabama issued a memo regarding a revision to the attendance manual following the Alabama immigration law, pertaining to all initial enrollments as of September 1, 2011 (Morton, 2011). All students who are registering in Alabama elementary and secondary school for the first time as of September 1, 2011 are required to submit an original or certified birth certificate, or supplemental documents, otherwise they will be reported to the State Department of Education (Morton, 2011). This will deter enrollment of children of undocumented migrant workers who also have the arduous task of maintaining regular school enrollment since they typically travel seasonally from state to state to harvest crops. Olivos and Mendoza (2010) also noted the importance that school educators/personnel play in allowing Latino parents access to educational meetings.

Access to higher education is very challenging for undocumented students due to: denial of admission, lack of access to student loan, and being charged out of state fees (when they have resided in the state) (Lopez, 2005). According to Professor Victor Romero (as cited by Lopez):

[W]ithout a guarantee that an undocumented person can achieve lawful immigration status following graduation from college, such a person will always live under the double threat of being ineligible to lawfully hold a job and possible 
removal from the United States. And since immigration regulation is a federal power, state legislatures could not tie academic achievement or state residency to immigration status. The power to change one's immigration status rests solely on Congresses shoulders. (p. 1404)

\section{The Dream Act}

The DREAM Act (Development, Relief, and Education for Alien Minors Act) (H.R. 6497) was first introduced in 2001; it passed the House by a vote of 216 to 198 on December 8, 2010, but was defeated in the Senate. The DREAM Act would have benefited not only the young people in "immigration limbo" who grew up in this country and graduated from high school, but it could have reduced the "federal deficit by $\$ 2.2$ billion over 10 years" (National Immigration Law Center, 2010, p. 1). In addition, according to the Congressional Budget Office (CBO), the DREAM Act would have decreased the federal budget by $\$ 1.4$ billion in 10 years due to increased tax revenues (The White House, 2011).

Qualifications for the DREAM Act included the following: undocumented students of good moral character who arrived to the U.S. prior to age 15 (at least five years prior to the enactment of the bill) and who are under the age of 30, would be eligible for conditional nonimmigrant status, after they were accepted to college, graduated from high school, or obtained a GED in the United States. Students who posed a security risk, committed crimes, or were ineligible, inadmissible, or removable based on certain other grounds, would not be eligible. Conditional nonimmigrant status gives individuals the eligibility to drive, work, go to school, obtain student loans, and be eligible for the federal work study program. The process involves 10 years of conditional nonimmigrant status demonstrating good moral character, not committing crimes, avoiding violation of travel restrictions, and paying back-taxes, followed by three years with a permanent resident status, and lastly becoming eligible to apply for U.S. citizenship.

The Illinois DREAM Act, SB 2185 (Illinois General Assembly, 2012; Immigrant Youth Justice League, 2011) gives hope to Illinois undocumented students who meet the criteria for inclusion to attend college and benefit from a privately-funded scholarship program. They can invest and save money for their education by using the Illinois Prepaid Tuition Plan.

\section{Prosecutorial Discretion}

On June 15, 2012 President Obama announced an immigration policy regarding the use of prosecutorial discretion by the Department of Homeland Security (DHS) in regards to the handling of cases of undocumented individuals who were brought to this country as children. Under this policy, undocumented individuals who meet the criteria will be allowed to remain in the Unites States for two years. In a memorandum issued by Janet Napolitano (2012), Secretary of Homeland Security, the following criteria must be met prior to considering prosecutorial discretion for the individual:

- $\quad$ came to the United States under the age of sixteen; 
- has continuously resided in the United States for at least five years preceding the date of this memorandum and is present in the United States on the date of this memorandum;

- is currently in school, has graduated from high school, has obtained a general education development certificate, or is an honorably discharged veteran of the Coast Guard or Armed Forces of the United States;

- has not been convicted of a felony offense, a significant misdemeanor or offense, multiple misdemeanor offenses, or otherwise poses a threat to national security or public safety; and

- is not above the age of thirty (Reno, 2012, p. 1).

This policy has been in effect since August 15, 2012 and has attracted a large number of qualified individuals.

\section{Immigrants are Job Creators and Tax Contributors}

According to the White House (2011) nearly 30\% of immigrants are more likely than non-immigrants to start a business, and they compose $16.7 \%$ of (all) new business owners in this country generating $\$ 67$ billion of the United State’s $\$ 577$ billion business income.

Immigrants started 25 percent of the highest-growth companies between 1990 and 2005, and these companies directly employ an estimated 220,000 people inside the United States. These immigrant-founded companies include Intel, Google, Yahoo, and eBay, which have all helped drive American leadership in the computer and internet revolutions and have stimulated business and job creation throughout our economy. These immigrants give the U.S. workforce an important economic advantage. Research shows that immigrants are more likely than U.S. born workers to start new businesses and are among the most prolific inventors in the American economy, generating ideas that lead to new products and more jobs in many sectors including pharmaceuticals and information technology. (White House, 2011, p. 11)

Paral (2006) reported that in Illinois, 38\% of college graduates are foreign born. Immigrants in the United States currently represent $47 \%$ of the engineers (with doctorate or bachelor's degrees), and 24\% of the scientists (White House, 2011). The new immigrant populations tend to be younger than native-born citizens, which helps counter the fiscal effects of the aging population in this country (Paral, 2006; White House, 2011). In Illinois, "The addition of immigrants permits the state to maintain workforce growth" (Paral, 2006, p. 2). The IRS estimates that "undocumented immigrants paid almost $\$ 50$ billion in federal taxes between 1996-2003. These taxes include payroll and social security (about $\$ 8.5$ billion per year), property (directly or as part of rental payments), and sales taxes” (White House, 2011, p. 13). Additionally, more than 114,000 immigrants are active-duty service members and represent nearly $8 \%$ of the U.S. Military (White House). As of January 2009, the White House reported that 20,000 immigrants who serve in the military have been naturalized. 


\section{Implications for Social Work Practice}

Social workers must confront conditions (social, political, and economic) that challenge the human rights of immigrants from a social justice perspective (Critelli, 2008; Ortiz, Garcia, \& Hernandez, 2012). Social workers and counselors serve in crucial roles such as: providing therapy and information and referral services, community activists, and change agents that drive social policy. Without comprehensive immigration reform, many children of undocumented immigrants live in fear that their parents and possibly they themselves may be deported. The children may benefit from social work and counseling services to help them process their fear of separation and loss of their parent(s) due to immigration status. Counseling services can also be offered to children who have been placed in foster care. Wessler (2011) conservatively estimates that 5,100 children of undocumented immigrants are placed in foster homes and make up $1.25 \%$ of children placed in foster care. Cultural sensitivity with this vulnerable population is a growing area of need. Referral services to appropriate agencies on an as-needed basis is crucial. The children may also benefit from free/reduced lunch and Kid Care since many live below the levels of poverty. Berk, Schur, Chavez, and Frankel (2000) reported that few undocumented immigrants access health care, with the exception of childbirth services.

Increasing school counseling programs is of utmost importance for the socialemotional well-being of children. Given the compulsory attendance law, school social workers and counselors are in a crucial position to offer support to all school-aged children, including the undocumented. School social workers can serve as a resource for the students and their families, given the recent memorandum on the revisions of the Alabama School Attendance Manual in relation to documentation needed for the enrollment of incoming students issued by the State Superintendent of Alabama. Some school social workers may presume that they do not have the skills or language to assist in this "immigration" situation; when in fact, school social workers are more than qualified to address this loss issue.

On November 26, 2011 (according to a San Antonio News Station) a young undocumented immigrant in McAllen, Texas committed suicide and left a note to his devastated family noting that he had no will to live because he was undocumented and not able to attend college. Many young students are devastated by the plight of their undocumented immigrant status because it causes not only emotional but financial turmoil, since they are not able to get a driver's license, get a job, attend college and pursue the "American dream." Many children were brought into this country when they were young and have only known this country to be their home. For the majority, their dominant language is English and they have lived and attended schools in this country. Social workers should advocate for comprehensive immigration reform.

Using a social justice theoretical framework, social workers have the skills to work with organizations and the media to bring to light the plight of immigrant families. Social workers are trained in community organization and should use this skill to advocate for immigrants. Child welfare agencies and caseworkers are challenged to provide services to diverse populations using cultural sensitivity. Social work practice should be child 
focused, strengths based, culturally competent, community based, individualized to meet the unique needs of the family, and offer family centered services (AHA, 2010).

\section{Implications for Social Work Education}

Given the growing number of deportations faced by immigrants in this country the impact this has on Latino school-aged children and their families is enormous (SPLC, 2011a). Social work education needs to continue to address global issues (transnational issues and immigration) in the social work curriculum. Social work macro practice (Netting, Kettner, McMurtry, \& Thomas, 2012) also needs to address the issues of the impact of immigration. Ortiz, Garcia, and Hernandez (2012) recommend that a "working with Latinos and immigrants" curriculum be developed by CSWE, BPD, NADD, and GADE (p. 201). Community organization courses need to address how to work with and empower the immigrant population (NCLR, 2011b). Advocacy groups have been on the forefront of emphasizing social events that impact vulnerable groups. Social workers can play a crucial role in community activism and organization and develop culturally sensitive curricula to work with immigrants.

Given the growing number of Latinos in this country, schools of social work must recruit and retain Latino students and faculty (Ortiz et al., 2012). Cultural and linguistic competence is necessary when working with racial and ethnic populations, is essential for their emotional well-being, and helps to reduce health disparities among these groups (Sanchez, Chapa, Ybarra, \& Martinez, 2012). Social work students need to be able to address and work with populations who are undocumented, given the growing number of undocumented persons and the increase in anti-immigrant legislation. Many state legislatures implement language that warns against those who provide services to the undocumented. Therefore, it is imperative that our national and state associations take a public stand against xenophobic anti-immigrant legislation, because it violates human and civil rights, and social and economic justice.

\section{Implications for Policy}

Human well-being can be achieved by creating policies and services that impact quality of life. Social workers are change agents who can provide leadership for such policies (Council of Social Work Education, 2008). State and national social work organizations can take the lead to support comprehensive immigration reform. Globalization also plays a role in transnational migration that cannot be overlooked. Comprehensive immigration reform must be addressed by the federal government, because without bipartisan leadership, many states can end up like Arizona, Alabama, Georgia, Utah, Indiana, and South Carolina, which have mirrored legislation that violates the civil and human rights of immigrant families and their children who are often citizens of the United States.

Immigration policy must minimize the pronounced waiting list for those who have applied for residency (Flynn \& Dalmia, 2008). Furthermore, immigration policy and reform should ensure immigrants the right to due process similar to that used for the criminal justice system. Currently, undocumented immigrants do not have the right to due 
process, which includes: Miranda warnings, lawyer access, right to a bail hearing, speedy trial, trial by jury, as well as restrictions against illegally-obtained evidence.

Many immigrants are held in detention camps for what appears to be an unlimited amount of time and are treated as criminals. In Illinois, approximately $77 \%$ of the immigrants being held are facing charges related to immigration and documentation issues rather than crimes that are violent in nature. This detention and deportation of undocumented immigrants is aimed at deterring their employment, yet it takes a terrible toll on the children and their families; many of which live below the poverty line.

"SB 1070-style laws impose unfounded mandates on police, jails, and courts; drive away workers, taxpayers, and consumers upon whom the state economy depends; and invite costly lawsuits and tourist boycotts” (Immigration Policy Center, 2011, p. 1). Few states can afford these economic consequences. Fitz and Kelley (2010) reported that four months after Arizona passed S. B. 1070, Arizona's Hotel and Lodging Association reported a loss of 15 million dollars in lodging revenues, but Fitz and Kelley estimated that 45 million dollars would have been a more accurate figure. Many farmers throughout the United States reported a loss of crops, as well as income due to the anti-immigrant legislation that drove their workers, many of which were undocumented, away. Many farmers reported that Americans would not take these hard labor jobs in the fields.

Churches and other faith-based organizations have been safe havens for the immigrant community and play a critical role in the distribution of services to support communities; social workers collaboration with these groups is beneficial. Some schools have played a positive role to support students who have faced deportation. Schools can make the enrollment process more user-friendly and not a deterrent for parents who may need an interpreter to register their children, or may not understand the educational system. School office staff may benefit from cultural sensitivity training, and social workers have the expertise to provide this training. In addition, schools should provide the necessary academic and emotional support to all enrolled students. An increase in early childhood education programs will provide children of immigrants who may speak another language at home the opportunity to learn English as they build their basic skills. School social workers and counselors play a crucial role in these settings, and, in addition, can offer counseling services for the children who have experienced a separation from their parents. Immigrant community organizations and leaders have provided a network to address concerns that impact the community and should have plans that are ready to implement in cases of need (Capps et al., 2007).

\section{Implications for Social Work Research}

The importance and need for further research and action on the impact of immigration on children, families, communities, and our nation is urgent and of utmost relevance to the body of research in the social work profession. State by state, the growing number of anti-immigrant legislation continues to fester and sever family ties, an important foundational element of our society. The well-being of vulnerable populations is at stake. 
Social workers have the expertise and the experience to contribute to research on the need for comprehensive immigration reform and the impact of immigration legislation on Latino families. Research is crucial to understand the implications that toxic and constant stress and trauma have on children of immigrants and Latino families. The growing number of children who are placed in foster care because their parents are detained or deported demands further study. Research is also needed on the undocumented victims of domestic violence. Further research is necessary on the impact that legal channels of immigration would have on the economy of the United States. Immigration reform is necessary and merits research. Paral (2006) reported that "...immigration policy is economic development policy” (p. 12).

\section{Discussion}

Many believe that immigration is primarily a Latino issue, when in reality immigrants come from diverse countries. The Latino population is one of the largest minority groups in this country and Latino families have been targeted by draconian antiimmigration legislations. Enforcement-only policies are devastating for immigrant families, their children, and our nation as a whole.

While the issue of undocumented immigration applies to a larger group, recent antiimmigrant legislation (state and local) has primarily targeted the Latino immigrants. In Arizona, SB 1070 led the way to racial profiling targeting the Latino population, many of whom are U.S. citizens. Latino families have endured the impact of massive detentions. Many Latinos in detention centers suffer abuse, neglect, and death. Five thousand one hundred children who are currently in foster care are there because their parents were placed in detention centers or deported and their parental rights were terminated (Democracy Now Organization; Wessler, 2011). The highest numbers of deportations in this country have been under the Obama administration and they carry a heavy toll on the Latino children and their families. Enforcement-only initiatives do not work.

According to the Immigration Policy Center (2011) the estimated cost for enforcing SB 1070-style immigration enforcement is astronomical. Ogden (2006) an Arizona sheriff, reported on the projected high costs of law enforcement (officers, time, costs); jail operations (per diem rates, additional jail beds); the building of additional jails (plan, staff, finance); and criminal agencies (county attorneys and support staff, court rooms, support offices) as they relate to Arizona SB 1070-style legislation. In addition to the issues brought up by Ogden (2006) and the Immigration Policy Center (2001) there is a loss to the economy (decrease in economic output, consumer purchasing power with the loss of workers, tax payers, and consumers, and tax revenue) as well as legal costs related to SB 1070-style legislation and "Secure Communities." Due to SB 1070, Arizona endured astounding economic impacts related to drops in tourism and boycotts.

It is imperative that lawmakers understand the economic contributions of Latinos in this country. Latino students will be the backbone of the U.S. economy (Dolan, 2009). All Latino students should be afforded their basic human right to an education. Many Latino families live in impoverished neighborhoods and their children attend schools with higher poverty levels. Education should be equitable for all children regardless of 
where they live. Education is crucial for reaching the American dream and the DREAM Act will provide students the opportunity to succeed. The DREAM Act could positively impact the economy by reducing the federal deficit (National Immigration Law Center, 2010) and decreasing the federal budget (White House, 2011). Prosecutorial discretion should be adhered to when the criteria is met by the undocumented individuals (Napolitano, 2012). With the aging of the baby boomer generation, immigrants who are typically young and can contribute to the labor pool will help offset the impact that the loss of employees has on society. "Immigrants are entrepreneurial and create jobs in the United States” (White House, 2011, p. 11).

From a social justice perspective, social workers must be at the forefront of advocacy for oppressed groups (including undocumented immigrants). There are many theoretical frameworks that can be used to address these issues. The social-emotional well-being of children who are separated from their parents can be understood using Bowlby's attachment theory. The social justice theoretical framework is of utmost relevance when dealing with this population. Social workers have the skills and expertise to provide leadership to those who enact policies. Social justice and systemic oppression can be addressed through social work practice, education, research, and policy.

\section{Conclusion}

Various racial, ethnic, and immigrant groups have endured systemic oppression throughout the history of this country. Latino families compose the largest immigrant group (Wessler, 2011) and they suffer the negative impact of these political, legal, economic, and social ramifications due to the anti-immigrant legislations. Comprehensive immigration reform is necessary at the federal level otherwise states will continue to enact legislation that violates the undocumented immigrants civil and human rights. The social, political, legal, and economic impact on these oppressed groups is enormous. In the Latino community racial profiling affects not only the undocumented, but also the U.S. citizens alike. The anti-immigrant legislations have an adverse effect on the socialemotional well-being of Latino children and their families (citizens and undocumented) who are separated due to detentions and massive deportations. When registration and school policies become exclusionary, they adversely affect the education of Latino children and young adults who are striving for a better future through academic excellence. The economic impacts of anti-immigrant legislation are complex: 1) they will increase economic hardships for many undocumented Latino families who are already living below the level of poverty due to their undocumented status, 2) there is an economic impact on our nation's economy, since undocumented immigrants pay federal, property, and sales taxes, as well as payroll, and social security, and 3) they place more financial burdens on states to enforce these legislation (the rising costs of detention centers, jails, and manpower, not to mention losses due to boycotts and their effect on tourism).

Social work is a profession that has fought against tenacious systems of oppression and must continue to advocate for social and economic justice, equality, and fairness for all (including the undocumented immigrants and their families). Jane Addams stated, "The good we secure for ourselves is precarious and uncertain until it is secured for all of 
us and incorporated into our common life.” The impact of immigration legislation on Latino families can be addressed through social work education, practice, research, and policy.

\section{References}

American Humane Association. (2010). A social worker's tool-kit for working with immigrant families-healing the damage, trauma and immigrant families in the child welfare system. Retrieved from http://americanhumane.org/children/professionalresources/program-publications/child-welfare-migration/tool-kits.html

American Psychological Association. (2012). Crossroads: The psychology of immigration in the new century. Report of the APA Presidential Task Force on Immigration. Washington, DC: Author. Retrieved from http://www.apa.org/topics/immigration/report.aspx

Berk, M. L., Schur, C. L., Chavez, L. R., \& Frankel, M. (2000). Health care use among undocumented Latino immigrants. Health Affairs, 19(4), 51-64. Retrieved from http://content.healthaffairs.org/contents/19/4/51

Bernstein, N. (2011, September 28). Companies use immigration crackdown to turn a profit. The New York Times. Retrieved from http://www.nytimes/2011/09/29/world/asia/getting-tough-on-immigrants-toturn-aprofit

Bess, A. (2011). The impact of immigration detention on children and families. National Association of Social Workers. Retrieved from http://www.naswdc.org/practice/intl/2011/HRIA-FS-84811.Immigration.pdf

Bowlby, J. (1980). Attachment and loss: Volume 1: Attachment ( $2^{\text {nd }}$ ed.) New York, NY: Basic Books.

Capps, R., Castañeda, R. M., Chaudry, A., \& Santos, R. (2007). Paying the price: The impact of immigration raids on America's children. Washington, DC: The Urban Institute. Retrieved from http://www.urban.org/publications/411566.html

Casas, J. M., \& Cabrera, A. P. (2011). Latino/a immigration: Actions and outcomes based on perceptions and emotions or facts? Hispanic Journal of Behavioral Sciences, 33(3), 283-303.

Chaudry, A., Capps, A., Pedroza, J. M., Castañeda, R. M., Santos, R., \& Scott, M. M. (2010). Facing our future: Children in the aftermath of immigration enforcement. Washington, DC: The Urban Institute.

Chaudry, A., \& Fortuny, K. (2010) Children of immigrants: Economic well-being. (Brief No. 4). Washington, DC: The Urban Institute. Retrieved from http://www.urban.org/publications/412270.html

Cleary, J. (2000). Racial profiling studies in law enforcement: Issues and methodology. (Information Brief) St. Paul, MN: Minnesota House of Representatives. Retrieved from http://www.house.leg.state.mn.us/hrd/pubs/raceprof.pdf 
Council on Social Work Education. (2008). Educational policy and accreditation standards. Retrieved on February 25, 2012, from http://www.cswe.org/Accreditation/Reaffirmation.aspx

Critelli, F. M. (2008). The impact of September $11^{\text {th }}$ on immigrants in the United States. Journal of Immigration and Refugee Studies, 6(2), 141-167.

Democracy Now Organization. (2011). Report: Thousands of U.S. -born kids languish in foster care as immigrant parents detained, deported. Retrieved from http://democracynow.org/2011/11/10/report_thousands_of_us_born_kids

Dolan, S. L. (2009). Missing out: Latino students in American schools. Washington, DC: National Council of La Raza.

Faulkner, M., \& Berger Cardoso, J. (2010). Mexican-American youth: The impact of generation and gender on outcomes in young adulthood. Journal of Immigrant \& Refugee Studies, 8(3), 301-315.

Fitz, M., \& Kelley, A. (2010). Stop the conference: The economic and fiscal consequences of conference cancellations due to Arizona's S.B. 1070. Washington, DC: Center for American Progress. Retrieved from http://www.americanprogress.org/issues/immigration/report/2010/11/18/8657/stopthe-conference

Fix, M., \& Passel, J. S. (2003). U.S. Immigration: Trends and implications for schools. Washington, DC: The Urban Institute. Retrieved from http://www.urban.org/publications/410654.html

Flynn, M., \& Dalmia, S. (2008, October). What part of legal immigration don’t you understand? Reason Magazine, p. 32. Retrieved from http://reason.com/assets/db/07cf533ddb1d06350cf1ddb5942ef5ad.jpg

Fortuny, K. (2010). Children of immigrants: 2008 State trends updates. (Brief No. 17). Washington, DC: The Urban Institute. Retrieved from http://www.urban.org/UploadedPDF/412212-children-of-immigrants.pdf

FRONTLINE. (2011). Lost in detention [video]. Available from http://video.pbs.org/video/2155873891/

Illinois Coalition for Immigrant and Refugee Rights. (2011). Immigration enforcement: The dangerous reality behind "Secure Communities". Chicago, IL: Author. Retrieved from http://icirr.org/sites/default/files/ImmigrationEnforcementTheDangerousRealityBehin dSecure\%20Communities-1.pdf

Illinois Coalition for Immigrant and Refugee Rights. (2012). Campaign against private immigration jail takes major step forward. Chicago, IL: Author. Retrieved from http://icirr.org/content/campaign-against-private-immigration-jail-takes-major-stepforward 
Illinois General Assembly. (2012, February 25). SB 2185. Retrieved from: http://www.ilga.gov/legislation/fulltext.asp?DocName=Sessionid=84\&GA=97\&Doc Ty

Immigration Policy Center. American Immigration Council. (2011, January). Checklist for estimating the cost of SB 1070-Style Immigration. Washington, DC: Author. Retrieved from http://elpasotimes.typepad.com/files/calculating_the_cost_of_sb1070_011911-1.pdf

Illinois Youth Justice League. (2011, June 7). Illinois Dream Act: The facts. Retrieved from http://www.iyjl.org/illinois-dream-act-the-facts/

Knight, M. (2012, February 25). Far from family, alone, homeless and still just 18. The New York Times. Retrieved from http://www.nytimes.com.

Lewis, T. (2011, September 29). Federal court upholds most of Alabama’s draconian anti-immigrant law. The Leadership Conference. Retrieved from: http://www.civilrights.org/archives/2011/09/1247-alabama.html

Lopez, M. P. (2005). Reflections on educating Latino and Latina undocumented children: Beyond Plyler v. Doe. Seton Hall Law Review, 35(4), 1373-1406.

Morton, J. B. (2011, August 1). Alabama school attendance manual revisions-September 1, 2011 (Act No. 2011-535). Retrieved from http://immigrationguidelines-blog.pdf

Napolitano, J. (2012, June 15). Exercising prosecutorial discretion with respect to individuals who came to the United States as children. Retrieved from http://i2.cdn.turner.com/cnn/2012/images/06/15/s1-exercising-prosecutorialdiscretion-individuals-who-came-to-us-as-children.pdf

National Council of La Raza. (2011a). National copycat landscape. Retrieved from http://www.nclr.org/index.php/issues and programs/immigration/policy and legisla tion details/state local immigration initiatives/arizonarelated_legislative_developments/national_copycat_landscape/

National Council of La Raza. (2011b). Not in our state: What community-based organizations can do to combat SB1070 legislation: Toolkit for advocates. Retrieved from http://www.nclr.org/images/uploads/pages/Not\%20in\%20Out\%20State\%20What\%2 0CommunityBased\%20Organizations\%20Can\%20Do\%20to\%20Combat\%20SB\%201070\%20Co pycat\%20Legislation.pdf

National Immigration Law Center. (2010, December). DREAM Act: Summary. Los Angeles, CA: Author. Retrieved from http://www.nilc.org/dreamsummary.html

Netting, F. E., Kettner, P. M., McMurtry, S. L., \& Thomas, M. L. (2012). Social work macro practice ( $5^{\text {th }}$ ed.). Boston: Pearson Education Inc.

Ogden, R. E. (2006). Fact sheet. Yuma County, AZ: Author. 
Olivos, E. M., \& Mendoza, M. (2010). Immigration and educational inequality: Examining Latino immigrant parents' engagement in U.S. public schools. Journal of Immigrant \& Refugee Studies, 8(3), 339-357.

Ortiz, L., Garcia, B., \& Hernandez, S. H. (2012). Why it is important for social work educators to oppose racist-based anti-immigration legislation. [Guest Editorial]. Journal of Social Work Education, 48(2), 197-203.

Paral, R. (2006). Illinois immigrants: Fueling prosperity in a changing economy. Chicago, IL: Illinois Coalition for Immigrant and Refugee Rights. Retrieved from http://www.robparal.com/downloads/Economic\%20Contributions\%20of\%20Illinois \%20Immigrants\%20a.pdf

Perez, S. M. (2000). U.S. Latino children: A status report. Washington, DC: National Council of La Raza. Retrieved from www.nclr.org/images/uploads/.../1381_file_US_LatinoChildren.pdfReno, J. (2012). Exercising prosecutorial discretion with respect to individuals who came to the United States as children. Department of Homeland Security. Retrieved from http://www.dhs.gov/xlibrary/assets/s1-exercising-prosecutorial-discretionindividuals-who-came-to-us-as-children.pdf

Romero, S. (2006). The impact of parental death on childhood bereavement (Unpublished doctoral area specialization paper). Barry University, Miami, FL.

Romero, S. (2009). Utilization of interventions by parentally bereaved children: The impact on symptoms of psychopathology (Doctoral Dissertation). Retrieved from Proquest.

Sanchez, K., Chapa, T., Ybarra, R., \& Martinez, O. (2012). Eliminating disparities through the integration of behavioral health and primary care services for racial and ethnic minority populations, including individuals with limited English proficiency: A literature report. U.S. Department of Health and Human Services Office of Minority Health and Hogg Foundation for Mental Health. Retrieved from http://www.hogg.utexas.edu/uploads/documents/OMH\%20Report FINALFINAL.pdf

Southern Poverty Law Center. (2011a, Fall). SPLS challenges Ala. Anti-immigrant law: New statute criminalizes father, Good Samaritans. SPLC Report, 41(3), 1, 8.

Southern Poverty Law Center. (2011b, Winter). State anti-immigrant laws. SPLC Report, 41(4), 2, 3.

Wessler, S. F. (2011). Shattered families: The perilous intersection of immigration enforcement and the child welfare system. New York, NY: Applied Research Center. Retrieved from http://arc.org/shatteredfamilies

White House. (2011). Building a $21^{\text {st }}$ century immigration system. Retrieved from http://www.whitehouse.gov/immigrationaction 


\section{Author note:}

Address correspondence to Sylvia Romero, Community Consolidated School District 46, Frederick School, 595 Frederick Road, Grayslake, IL. 60030. E-mail:

romero.sylvia@d46.org 